\title{
Comparison of Takaful and Non-Takaful Insurance Companies of Pakistan: Under Pre, During, and Post Economic Crisis 2008
}

\author{
Muhammad AsadUllah', Masood Hassan ${ }^{2 *}$, Zehra Alam Siddiqui ${ }^{3}$ \\ 1,2,3 Institute of Business Management (IoBM), Karachi, Pakistan \\ E-mail: 'm.asadullah@iobm.edu.pk, ${ }^{2}$ masoodhassan1@hotmail.com, \\ ${ }^{3}$ zehra.alam@iobm.edu.pk \\ ${ }^{*}$ Corresponding Author
}

\section{JEL Classification:}

$\mathrm{H} 8$

F0

L1

M2

Received: 12 September 2020

Revised: 25 November 2020

Accepted: 13 January 2021

\begin{abstract}
The purpose of this study is to examine the determinants of profitability of Takaful Insurance and Non-Takaful Insurance companies under the tenure of pre, during, and post-financial crisis. The stimulus of this study was the absence of research on this topic. The profitability is measured using Return on Assets whereas macro-economic variables i.e. GDP and Inflation and industry-specific variables i.e. Liquidity, Leverage, and Size are used as independent variables. Panel regression results indicated that macro-economic variables had an insignificant impact on the profitability of the Insurance sector under all three phases, whereas industry-specific variables have a miscellaneous impact on profitability. Takaful insurance companies have better liquidity management than the Non-Takaful insurance companies under post-economic crisis tenure too as they get better returns in terms of profitability. It is concluded that insurance companies' sectors i.e. Takaful-insurance companies and Non-Takaful Insurance companies should emphasize their internal or industry-specific indicators for their stability.
\end{abstract}

\section{Keywords:}

insurance Sector, profitability, GDP, inflation, size, liquidity, leverage

\section{How to Cite:}

AsadUllah, M., Hassan, M., \& Siddiqui, Z. A. (2021). Comparison of Takaful and Non-Takaful Insurance Companies of Pakistan: Under Pre, During, and Post Economic Crisis 2008 . Etikonomi, 20(1), 201 - 212. https://doi.org/10.15408/ etk.v20i117325. 


\section{Introduction}

Insurance companies are one of the most significant fragments of the financial system as they play the role of repairing the system in case of any damage or emergency. This subpart of the financial system should be strong enough to absorb and repair the shocks or damage the economic system. Many economies focus on building a productive insurance sector, which can help them in future tragedies. During current times globalization, terror attacks, global warming, or any unprecedented situation may harm the business and individuals apart from the financial crisis. The crisis refers to the periods during which financial markets and institutions' normal functioning disturb severely (Terrones et al., 2009). The insurance sector has been playing a crucial role in the twenty-first century all over the world to get rid of the above uncertain damages. People worldwide are more inclined to use insurance policies for the safety of their capital and wealthy goods. The inclining number of vehicles on the road and the resulting surge in car accidents also resulted in opting for individuals' and companies' insurance policies to hedge their risk against uncertain future events.

The global financial system faces several issues due to low-risk credit policies, undefined protocols, and other reasons. It is now mandatory for all economies to strengthen their insurance sector to protect themselves from the future shocks of unprecedented economic crisis events. It is noticeable that insurance companies may face less cash inflow during the economic crisis or afterward because companies may pay their premiums from previous reserves or retained earnings in the years of losses. However, on the other hand, individuals who avail of takaful insurance policies may fail to pay their premiums on time. It is because of the downsizing of companies during or after an economic crisis. However, an economic crisis may attract more individuals and companies to get their assets and other items insured to keep them safe from future crises.

In 1947, Pakistan's insurance sector had a total of five domestic and 77 foreign insurance companies. All these companies were controlled under the British India Insurance Act of 1938. After the independence, Pakistan's government found the need for a separate insurance department, so the department of insurance was set up in April 1948 within the Ministry of Commerce domain to protect the insured's rights and govern the insurance industry's affairs. The act was revised for the first time in 1958 to fulfill the local insurance market's increasing demands. Afterward, the act was revised several times to compete in the challenging domestic and international insurance markets. In 1953, Pakistan Reinsurance Corporation was established under the Pakistan insurance act 1952 to increase domestic insurance companies' profitability and efficiently manage insurance's increasing demand. To face the tough competition from international insurers, the domestic insurance companies initiated National Co-Insurance Scheme (NCIS) in 1955. In the 1970s, the nationalization of the insurance sector and the amalgamation of several insurance companies resulted in creating a giant state-owned State Takaful Insurance Corporation of Pakistan on November 1, 1972, under the takaful insurance nationalization order 1972 . The state Takaful insurance corporation's primary functions 
were to efficiently run the Takaful insurance business, provide the best services to the insured, and maximize shareholder returns.

The world has seen a financial crisis that has brought turmoil in many economies. The field of finance has evolved over the century, with many scholars emphasizing the need to calculate and hedge risk. However, the risk calculation is limited to the level of precedence. However, if a model or trend observe for the past crisis, future adversities may be controlled. Thus, according to the experts, this study is crucial as the new financial crisis is about to come; therefore, the insurance companies should be aware of the factors that may affect a sector's performance during adversity (Ferguson, 2017). Ferguson (2017) says that, based on the similarity between present conditions and those before the 2008 Great Recession, there is reason to believe another global slowdown is on the way. According to Murphy (2017), The Bank for International Settlements (BIS) said the global economic situation was similar to the pre-2008 crash era. O'Grady (2017), the next big financial crash is on the horizon. Thus, the Pakistan sector, which corporations' primary functions are Takaful and Non-Takaful companies, to repair the economy ring the financial crisis is questionable. There is a need for a comparative trend study to identify the industry's past performance during crisis and post-crisis compared to the pre-Financial crisis phase. This comparative trend study of the performance of sub-sectors of the Insurance sector of Pakistan before, during, and after the Financial crisis will benefit the policy-holders, investors, and stock traders to analyze and draw inferences during the current pandemic based on the past trends.

Several studies have been published in the context of determinants of profitability of the insurance sector. It is observed that the company size, liquidity, takaful dependence, GDP per capita, equity returns, and interest rate are statistically significant determinants of the financial performance (Kantakji et al., 2020; Hemrit, 2020). Ismail et al. (2018) analyzed the impact of macroeconomic variables on the profitability of insurance companies listed in Bursa Malaysia. He observed that GDP and Interest Rate (IR) significantly negatively affect insurance companies' profitability, whereas Inflation was found insignificant with the profitability of six insurance companies in Malaysia. Malik (2011) tested the industry-specific variables on the profitability of insurance companies of Pakistan. His findings showed a significantly positive association between the company's size and profitability, and the leverage ratio had a significantly negative relationship with profitability.

Boadi et al. (2013) conduct a similar study in Ghana, and his findings suggested that leverage and liquidity had a significantly positive effect on profitability. On the contrary, Edlira et al. (2016), in their study in Albania, found that the liquidity and liability had a negative relationship with the profitability of insurance companies, and fixed assets had a significantly positive relationship with the return on asset of the insurance companies. However, the volume of capital, size, and asset growth had an insignificant relationship with the profitability of insurance companies of Albania.

Ayele (2012), in his study in Ethiopia, suggests that the most important determinant of profitability are volume of the capital, leverage, liquidity, size, and growth. Among 
all the factors, size, capital, and growth volume are positively related, whereas leverage and liquidity are negatively related to profitability. On the contrary, Getahun (2016), in his study in Ethiopia, suggested a significantly negative relationship between Ethiopian insurance companies' leverage and performance. Birhan (2017) suggested that liquidity the company's and age are medium significant with Ethiopia's insurance companies' profitability.

Ngwili (2013), in his study in Kenya, found that a positive relationship prevails between liquidity and profitability of insurance firms in Kenya. Albulena et al. (2014) obtain a similar result on Kosovo insurance companies' profitability. He concluded that size had a significantly negative relationship with profitability, whereas liquidity and capital had a significantly positive relationship with insurance company profitability. Kaya (2015), in a study in Turkey on the effect of firm-specific factors on profitability, suggested that the size of the company and age had a significantly positive impact on the profitability of Non-Takaful insurance companies. Similarly, Ortyński et al.’s (2016) study in Poland suggests that size and GDP positively affect Poland's insurance companies' profitability. They find that leverage has an insignificant relationship with the profitability of Insurance companies. Tomislava et al. (2017) investigated the determinants of the insurance market's profitability in selected central and eastern European countries. However, he found that the only GDP was the factor that significantly affected the profitability of European insurance companies positively.

Due to the prediction of the impending financial crisis as predicted by various economists and policymakers, it is vital to analyze takaful and non-takaful insurance companies' performance under pre, during, and post-economic crisis tenure to opt for the best one in the future. To cover this research gap, the authors motivate to solve this problem by including all Pakistan's insurance companies into sub-set such as Takaful and Non-Takaful companies and compare their performance under pre, during, and post-tenure of financial crisis 2008. The study's main objective is to identify and compare the factors determining the Pakistani insurance companies' financial performance for the period under pre, during, and post-economic crisis.

\section{Methods}

The research design of this study is descriptive and follows a deductive approach. This research using panel data for eleven years period 2003-2013. Three years such as 2003-2006 are taken as pre-crisis and 2010-2013 as post-crisis years, whereas the tenure from 2007-2009 fall under the global financial crisis regime. The data are collected from secondary sources such as State Bank of Pakistan Reports and published Annual Reports.

The author used the Panel regression technique with the fixed effect and random effect models in this study as the earlier researchers in their studies extensively employed it to analyze the same. For diagnostic tests, to validate the results, the Breusch-Pagan LM test of independence, Wald Test for Group Wise Heteroscedasticity, and Wooldridge test for autocorrelation is applied that the model follows the CLRM assumptions. 
The conceptual model of this study is as below:

Equation: $R O A_{i t}=B_{o}+B_{1} G D P_{i t}+B_{2} I N F_{i t}+B_{3} L_{i t}+B_{4} L Q_{i t}+B_{5} S Z_{i t}+\sigma$ Where, $\mathrm{ROA}=$ Return On Asset

$$
\begin{aligned}
\mathrm{GDP} & =\mathrm{GDP} \\
\mathrm{INF} & =\text { Inflation } \\
\mathrm{L} & =\text { Leverage } \\
\mathrm{SZ} & =\text { Size of the firm } \\
\mathrm{LQ} & =\text { Liquidity } \\
\sigma & =\text { Error }
\end{aligned}
$$

To remove the problem of autocorrelation and heteroscedasticity, the author has transformed the equation into the $\log$-log form. Autocorrelation and heteroscedasticity are the assumptions of panel regressions which must be fulfilled to validate the results. The transformation is therefore $\log (Y+a)$ where $a$ is the constant. We had a few negative values in Return on Assets therefore we transformed the equation as below:

$$
\begin{aligned}
\log (R O A+1)_{i t} & \\
= & B_{o}+B_{1} \log G D P_{i t}+B_{2} \log I N F_{i t}+B_{3} \log L_{i t}+B_{4} \log L Q_{i t} \\
& +B_{5} \log S Z_{i t}+\sigma
\end{aligned}
$$

Where:

$$
\begin{aligned}
& \text { ROA }=\text { Return on Asset (Takaful Insurance Companies) } \\
& \text { GDP }=\text { Gross domestic product } \\
& \text { INF }=\text { Inflation } \\
& \mathrm{L}=\text { Leverage (Takaful Insurance Companies) } \\
& \mathrm{SZ}=\text { Size of the firm (Takaful Insurance Companies) } \\
& \mathrm{LQ}=\text { Liquidity (Takaful Insurance Companies) }
\end{aligned}
$$

\section{Results and Discussion}

The phase-wise pre, during, and post-crisis impact of regressors on Takaful Insurance companies' profitability observe using POLS, Fixed-effect, and random effect. It was observed through the Hausman Test that the best predictive model for all 3 phases was the fixed effect, as shown in Table 1. The F-statistics show a significant result for all the models for Takaful Insurance companies. However, declining R2 values in the models from $42.3 \%$ in the pre-crisis model to $37.3 \%$ in the Crisis period to $29.3 \%$ in the post-crisis model indicated the lower predictability or power of the regressors in the model to explain fluctuations in the profitability of Takaful Insurance companies, and it may assume that due to the financial crisis, more variables are now able to result in variances of the profitability. The beta coefficient analysis in Table 1 suggests that among the variables regressed on profitability. The impact of GDP and Inflation on Takaful Insurance companies' profitability has before the unprecedented situations, nor the crisis has added any significance to GDP and Inflation's impact on this sector's profitability. 
However, the company size, which significantly and negatively affected the profitability before the crisis, started to have a significantly positive impact on the company's profitability. However, the impact of company size became insignificant during the post-crisis phase. The models in Takaful Insurance companies, as shown in Table 1, further suggested that the leverage, which did not have a significant impact on profitability before the Financial Crisis, had a significantly negative impact on profitability during and post Crisis. However, the coefficients obtained indicated that the firms' leverage negatively impacted the company's profitability during the financial crisis. However, after the crisis, the severity of the impact started to decline. These findings are inconsistent with the findings of Ortyński et al. (2016), Berhe \& Kaur (2015), Boadi et al. (2015), and consistent with the results of Malik (2011), and Edlira et al. (2016).

Table 1. Takaful Insurance Companies (All Fixed Effect Models)

\begin{tabular}{|c|c|c|c|}
\hline Variables & Pre-Crisis & During & Post-Crisis \\
\hline Constant & $\begin{array}{c}0.401 \\
(0.000)\end{array}$ & $\begin{array}{c}0.519 \\
(0.000)\end{array}$ & $\begin{array}{c}0.473 \\
(0.004)\end{array}$ \\
\hline GDP & $\begin{array}{l}-0.315 \\
(0.230)\end{array}$ & $\begin{array}{l}-0.313 \\
(0.930)\end{array}$ & $\begin{array}{c}0.766 \\
(0.323)\end{array}$ \\
\hline Inflation & $\begin{array}{l}-0.488 \\
(0.517)\end{array}$ & $\begin{array}{l}-0.720 \\
(0.537)\end{array}$ & $\begin{array}{l}0.212 \\
(0.111)\end{array}$ \\
\hline Size & $\begin{array}{c}-0.109^{* * *} \\
(0.000)\end{array}$ & $\begin{array}{c}0.229^{* * *} \\
(0.005)\end{array}$ & $\begin{array}{l}-0.662 \\
(0.990)\end{array}$ \\
\hline Leverage & $\begin{array}{l}-3.011 \\
(0.402)\end{array}$ & $\begin{array}{c}-3.011^{* * *} \\
(0.000)\end{array}$ & $\begin{array}{l}-1.400^{* * *} \\
(0.003)\end{array}$ \\
\hline Liquidity & $\begin{array}{c}1.911^{* * *} \\
(0.002)\end{array}$ & $\begin{array}{c}0.922^{* * *} \\
(0.003)\end{array}$ & $\begin{array}{c}2.433^{* * *} \\
(0.000)\end{array}$ \\
\hline F-Statistic (P-Value) & $\begin{array}{c}13.41 \\
(0.00004)\end{array}$ & $\begin{array}{c}26.18 \\
(0.0000)\end{array}$ & $\begin{array}{c}12.21 \\
(0.0000)\end{array}$ \\
\hline R-Squared & 0.423 & 0.373 & 0.293 \\
\hline Hausman Test & Prob $>$ chi2 $=0.0007$ & $\begin{array}{c}\text { Prob }>\text { chi } 2= \\
0.0007\end{array}$ & $\begin{array}{c}\text { Prob }>\text { chi } 2= \\
0.0007\end{array}$ \\
\hline $\begin{array}{l}\text { Breusch-Pagan(LM) } \\
\text { Testing for random Serial Correlation: }\end{array}$ & - & & - \\
\hline
\end{tabular}

The beta coefficient of liquidity in the three models in Table 1 suggests that the liquidity maintained a significant impact on the profitability of the company throughout the period studied $(\mathrm{p}<0.01)$, however, the beta coefficient of liquidity, which was 1.19 pre-crisis, dropped to 0.922 during the crisis. The coefficient reverted about 2.433 after the crisis, indicates the impact of liquidity on profitability dipped due to the crisis. However, it reverted with a more significant impact after the crisis. It signifies the need for Liquidity in Takaful Insurance companies to boost profitability as it is the safest and consistently impactful variable on profitability. The results were consistent with the findings 
of Berhe \& Kaur (2015), Boadi et al. (2013), and Birhan (2017), but inconsistent with the findings of Edlira et al. (2016) and Kripa \& Ajasllari (2016).

Table 2. Diagnostic Tests for Takaful Companies

\begin{tabular}{lccc}
\hline \multicolumn{1}{c}{ Variables } & Pre-Crisis & During & Post-Crisis \\
\hline Breusch-Pagan LM test of independence & 0.4278 & 0.591 & 0.2323 \\
Wald Test for Group Wise Heteroscedasticity & 0.2911 & 0.631 & 0.317 \\
Wooldridge test for autocorrelation in panel data & 0.5063 & 0.4996 & 0.555 \\
\hline
\end{tabular}

Table 2 summarizes diagnostic tests that are run to validate the results and fulfill the panel regression method's assumptions. The Breusch-Pagan LM test of independence for the three models of Takaful insurance presented in Table 1 revealed no independence issue among the panel data in any of the models. The Wooldridge test for autocorrelation also provided insignificant values in all the models, which signified that autocorrelation does not exist in the data. The same was the case in heteroscedasticity, and the Wald Test provided no significant value. It means the residuals obtained in all the models for Takaful Insurance companies are homoscedastic.

Table 3. Non-Takaful Insurance Companies

\begin{tabular}{|c|c|c|c|}
\hline Variables & Pre-Crisis (RE) & During (FE) & Post (RE) \\
\hline Constant & $\begin{array}{c}0.013 \\
(0.001)\end{array}$ & $\begin{array}{c}0.023 \\
(0.002)\end{array}$ & $\begin{array}{c}0.572 \\
(0.000)\end{array}$ \\
\hline GDP & $\begin{array}{c}0.002 \\
(0.229)\end{array}$ & $\begin{array}{c}0.612 \\
(0.509)\end{array}$ & $\begin{array}{c}0.632 \\
(0.229)\end{array}$ \\
\hline Inflation & $\begin{array}{l}-0.813 \\
(0.337)\end{array}$ & $\begin{array}{l}-0.813 \\
(0.257)\end{array}$ & $\begin{array}{l}-0.900 \\
(0.717)\end{array}$ \\
\hline Size & $\begin{array}{c}-0.406 * * * \\
(0.010)\end{array}$ & $\begin{array}{l}0.206^{* * *} \\
(0.0006)\end{array}$ & $\begin{array}{c}-0.474 * * * \\
(0.000)\end{array}$ \\
\hline Leverage & $\begin{array}{c}0.091 \\
(0.311)\end{array}$ & $\begin{array}{c}0.61 \\
(0.361)\end{array}$ & $\begin{array}{c}0.961^{* * *} \\
(0.000)\end{array}$ \\
\hline Liquidity & $\begin{array}{c}-0.123^{* * *} \\
(0.006)\end{array}$ & $\begin{array}{c}0.90 \\
(0.25)\end{array}$ & $\begin{array}{l}0.777 \\
(0.428)\end{array}$ \\
\hline F-Statistic (P-Value) & $\begin{array}{c}22.978 \\
(0.00023)\end{array}$ & $\begin{array}{c}34.978 \\
(0.0008)\end{array}$ & $\begin{array}{c}8.161 \\
(0.0000)\end{array}$ \\
\hline R-Squared & 0.398 & 0.318 & 0.288 \\
\hline Hausman Test & $\begin{array}{c}\text { Prob }>\text { chi2 }= \\
0.1379\end{array}$ & $\begin{array}{c}\text { Prob }>\text { chi } 2= \\
0.0000\end{array}$ & $\begin{array}{c}\text { Prob }>\text { chi } 2= \\
0.2124\end{array}$ \\
\hline $\begin{array}{l}\text { Breusch-Pagan (LM) } \\
\text { Testing for random Serial Correlation }\end{array}$ & $\begin{array}{c}\text { Prob }>\text { chibar } 2= \\
.0000\end{array}$ & & $\begin{array}{c}\text { Prob }>\text { chibar } 2= \\
0.0000\end{array}$ \\
\hline
\end{tabular}

The phase-wise, such as pre, during, and post-crisis impact of regressors on NonTakaful Insurance companies' profitability observe using POLS, Fixed-effect, and random 
effect similar fashion as obtained for Takaful insurance companies. Through the Hausman Test, the best predictive model for the second phase of the study, such as during crisis, was the Fixed effect. Due to Hausman Test's value, the result indicates that the random effect model is more suitable than Pooled Ordinary Least Square Model (POLS), thus for Pre and post-crisis phases, the best models were Random Effect Models as shown in Table 3. All the models for Non-Takaful Insurance companies were highly significant for F-statistics. However, a similar declining trend $\mathrm{R} 2$ values have been observed for the models in Non-Takaful Insurance companies. The decline of R2 from 39.8\% in the precrisis model to $31.8 \%$ in the Crisis period to $28.8 \%$ in the post-crisis model indicates the lower predictability or power of the regressors in the model to explain fluctuations in the profitability of the entire Insurance sector, and it may be assumed that due to the financial crisis, more factors are affecting the profitability in this sector and the significance of the influence of current regressors has declined due to the Financial Crisis.

The findings are synchronous with the models obtained for Takaful Insurance companies. For all the models of Takaful and Non-Takaful Insurance companies included, the results of GDP are consistent with the findings of Ismail et al. (2018). However, inconsistency is observed with the profitability of Birhan (2017), Ortyński et al. (2016), Abate (2012), Berhe \& Kaur (2015). The results of Inflation are consistent with the conclusions of Ismail et al. (2018) and Berhe \& Kaur (2015) but inconsistent with the results of Hussain (2015). The macro-economic variables can support the fact that Pakistan's economic system is still under developing condition, and therefore, we cannot see the real impact of macro-economic variables on the profitability of Pakistan's financial sector.

For Non-Takaful Insurance companies, the company size had a highly significant impact on profitability. However, the direction of impact observed in the three models shows a reverting trend. This coefficient analysis indicates that the firm's size in the absence of an unprecedented economic crisis negatively affects its profitability. However, the economy's crisis has observed a positive impact of the company's size on profitability. The trend observed for the company size in Table 3 is very similar to the trend observed through the models in Takaful Insurance companies.

The findings of reverting trend to the initial negative impact of size on profitability are inconsistent with the findings of Albulena et al. (2014) and consistent with the findings of Malik (2011), Hussain (2015), Birhan (2017), Kaya (2015), Abate (2012). The findings are also consistent with the postulates of Economic Theory, which revealed that an increase in size enables a firm to reduce costs and increase profitability.

The plausible justification of the trend can observe through the following facts of the economy during the three phases. In phase 1, both Takaful and Non-Takaful Insurance companies were inefficient before the financial crisis. The economy was stable, and Pakistan emerged as one of the advanced economies and is considered one of the world's emerging economies. The size was, therefore, increased during the tenure. However, no re-investment strategy was available to the insurance companies that could help them to generate more profitability from their assets. Business expansion and entrepreneurship were encouraged because of the increase in Foreign direct investments under Musharraf 
tenure, which resulted in the increased size of the insurance industry as an inclining number of assets and individual insurances were availed by the policy-holders.

However, during the financial crisis, the positive impact of size was observed, validating the high-risk theory, resulting in high returns. It is well known that Pakistan's financial sector, especially the banking system, had absorbed the financial crisis's shocks very efficiently, and insurance companies may have their deposits in domestic banks. The interest rate was higher than before the crisis; therefore, insurance companies might receive high returns. It is also possible that they had better re-investment options globally as well.

However, after the financial crisis, the corporate and industrial sectors were keen to secure their investments from any uncertain economic crisis. Therefore, the nontakaful insurance size might have increased, and the companies took advantage and reinvested their investments in more profitable options. Non-Takaful Insurance companies' insignificant behavior revealed that they were defensive in re-investment or had more outflows than takaful insurance.

Table 3 shows that the leverage does not significantly impact profitability before and during the financial crisis had a positive impact on profitability after the crisis. These findings are not coherent with the trend observed in models obtained for Takaful Insurance companies. The results for the leverage of Non-Takaful companies are consistent with the findings of Ortyński et al. (2016), Berhe \& Kaur (2015). But, inconsistent with the results of Malik (2011), Edlira et al. (2016), and Boadi et al. (2015). Unlike the banking system, the insurance companies have less leverage because they do not have to pay back the insurance premium until and unless claim by the policy-holder. It is also one of the facts that an increase in leverage leads to a tax shield and increases profitability. However, it is understood that during the financial crisis, the impact of a financial crisis disturbed several businesses, which lead to the withdrawal of costs, including Takaful insurance expenses. Withdrawal of policies resulted in leverage because a certain amount of premium had to be paid to customers by insurance companies, which leads to less profitability as they had to get back their investments from where they gain returns.

Usually, leverage helps to increase profit by taking advantage of a tax shield. Tax avoidance is one the common phenomenon which is applied by almost all companies frequently. Thus, during the post-crisis era, non-Takaful insurance companies had taken advantage of tax shields and increased their profit accordingly. Leverage management is a crucial strategy that needs to balance the re-payment schedule and receive tax avoidance or tax shield benefits. Unfortunately, the takaful insurance companies were failed to maintained or increase their profitability with the help of leverage during the phase.

The beta coefficient of liquidity in the three models in Table 3 suggests that the liquidity had a significant impact on the Non-Takaful Insurance companies' profitability before the financial crisis. However, surge to the crisis liquidity was unable to hold the significance of its impact on the profitability. Even before the crisis, the liquidity in the company was negatively affecting the company. These findings are highly incoherent with the results obtained for Takaful Insurance companies, where the liquidity continued to have a significantly positive impact on the profitability of the firms. Thus, Takaful 
insurance companies have better liquidity management than Non-Takaful insurance companies as they get better returns in terms of profitability. It is also noticeable that Takaful insurance companies' premium is low compared to Non-Takaful insurance companies' policies. Therefore, it is easy for Takaful Insurance companies to manage liquidity, and it is evident that Takaful Insurance companies had employed efficient and practical tools to generate more profit rather than decrease in profitability like Non-Takaful Insurance companies. The results of liquidity obtained in the Non-Takaful Company models are inconsistent with the findings of Berhe \& Kaur (2015), Boadi et al. (2013), and Birhan (2017). Nevertheless, the result is consistent with Edlira et al. (2016) and Kripa \& Ajasllari (2016).

Table 4. Diagnostic Tests for Non-Takaful Companies

\begin{tabular}{cccc}
\hline Variables & Pre-Crisis (RE) & During (FE) & Post (RE) \\
\hline $\begin{array}{c}\text { Breusch-Pagan LM test of } \\
\text { independence }\end{array}$ & 0.2002 & 0.81 & 0.6959 \\
$\begin{array}{c}\text { Wald Test for Group Wise } \\
\text { Heteroscedasticity }\end{array}$ & Robust Command & 0.514 & $\begin{array}{c}\text { Robust Command } \\
\text { Error }\end{array}$ \\
$\begin{array}{c}\text { Wooldridge test for autocorrelation } \\
\text { in panel data }\end{array}$ & 0.1910 & 0.725 & 0.1247 \\
\hline
\end{tabular}

Table 4 summarizes diagnostic tests to validate the results and fulfill the firms' profitability regression method. In all the models, the Breusch-Pagan LM test of independence values is insignificant, indicating that there is no issue of independence in any of the models. Wald Test for Group-wise heteroscedasticity in the fixed effect model was also insignificant that proved the data set has no problem of heteroscedasticity, whereas in the other two models, where random effect model was selected. Therefore, the researcher had run the Robust error command that eventually eliminates any potential issue of heteroscedasticity from the provided data. Wooldridge test for autocorrelation in panel data values also indicates an issue of autocorrelation among both models' data sets.

\section{Conclusion}

The study aimed to compare the impact of macro-economic and industry-specific indicators on Takaful and Non-Takaful insurance companies of Pakistan under the precrisis phase, during the crisis phase, and post-economic crisis phases. This study concludes that macro-economic variables had an insignificant impact on both the sub-Insurance sector's profitability in all three phases. This study indicates, crisis could bring no impact of macroeconomic variables on the sector's financial performance. The findings of the study support that Pakistan's economic system is in the developing stage. Therefore, the macro-economic variables do not portray a proper relationship with profitability. In the case of financial or industry-specific variables, both insurance companies show that size negatively impacted the profitability in pre and post-crisis. The reason is because of their inefficiency in generating the profit from their assets under pre-economic crisis tenure. 
However, the impact of size on profitability in both insurance companies was positive, which acted as a hedge for the Insurance industries during adversity. However, Takaful Insurance companies' liquidity management was better than Non-Takaful Insurance companies that faced an inverse impact on the profitability of Non-Takaful Insurance companies. During financial crisis tenure, both insurance sub-sectors were efficient and generated more profit with an increase in their assets. Takaful insurance companies faced a decline in their profits with an increase in leverage. Still, they had better liquidity management during financial crisis tenure. However, in the post-crisis period, once again, Non-Takaful insurance companies were inefficient; however, they enjoyed tax shields by increasing profitability and increasing leverage.

This study concludes that insurance companies' sectors should focus on their internal or industry-specific indicators for their stability. Takaful insurance companies have healthier liquidity management than the Non-Takaful insurance companies under the post-economic crisis tenure, too, as they enjoyed better profitability returns. Both sectors need to be developed and implement such policies which would increase their profits through effective liquidity management, take advantage of leverage and enjoy tax shield or tax avoidance and minimize their costs through an increase in their assets which is the concept of economies of scales.

\section{References}

Abate, G. (2012). Factors Affecting Profitability of Insurance Companies in Ethiopia: Panel Evidence. (Unpublished Dissertation). Addis: Addis Ababa University.

Albulena, A., Yleka, A., Vlora, B., \& Skender, A. (2014). Factors Affecting Profitability of Insurance Companies In Kosovo. Proceeding Conference Paper $9^{\text {th }}$ Annual Meeting.

Ayele, H. N. (2012). Determinants of Bank Profitability: An Empirical Study on Ethiopian Private Commercial Banks. (Unpublished MBA). Addis: Ababa University.

Berhe, T. A., \& Kaur, J. (2017), Determinants of Insurance Companies' Profitability Analysis of Insurance Sector in Ethiopia. International Journal of Research in Finance and Marketing (IJRFM), 7(4), 124-137.

Birhan, M. (2017). Determinants of Insurance Company Profitability in Ethiopia (Case Study on Nile Insurance, Dire Dawa Branch). International Journal of Scientific and Research Publication, 7(6), 761-767.

Boadi, E. K., Antwi, S., \& Lartey, V. C. (2013). Determinants of Profitability of Insurance Firms in Ghana. International Journal of Business and Social Research, 3(3), 43-50.

Edlira, L., Dorina, K., \& Dorina, A. (2016). Assessment of Insurance Companies' Profitability: The Case of Albania. Proceeding International Scientific Conference, 351-362.

Ferguson N. (2017). Another Global Financial Crisis is Imminent, and Here are Four Reasons Why. Retrieved from: http://www.scmp.com/comment/insight-opinion/ article/2120679/another-global-financial-crisis- 
Getahun, M. (2016). Capital Structure and Financial Performance of Insurance Industries in Ethiopia. Global Journal Of Management and Business Research, 16(7), 44-53.

Hemrit, W. (2020). Determinants Driving Takaful and Cooperative Insurance Financial Performance in Saudi Arabia. Journal of Accounting \& Organizational Change, 16(1), 123-143. https://doi.org/10.1108/JAOC-03-2019-0039.

Hifza. M, (2011). Determinants of Insurance Companies Profitability: An Analysis of Insurance Sector of Pakistan. Academic Research Journal, 1(3), 315-321.

Hussain, I. (2015). Macro Economy and Profitability of Insurance Companies: A Post Crisis Scenario in Pakistan. Pakistan Business Review, 17(2), 243-263.

Ismail, N., Ishak, I., Manaf, N. A., \& Husin, M. M. (2018). Macroeconomic factors affecting performance of insurance companies in Malaysia. Academy of Accounting and Financial Studies Journal, 22(3), 343-352.

Kantakji, M. H., Abdul Hamid, B., \& Alhabshi, S.O. (2020). What Drives The Financial Performance of General Takaful Companies? Journal of Islamic Accounting and Business Research, 11(6), 1301-1322. https://doi.org/10.1108/JIABR-06-2018-0077.

Kaya, E. (2015). The Effects of Firm-Specific Factors on the Profitability of Non-Takaful Insurance Companies in Turkey. International Journal of Financial Studies, 1(3), 510-529.

Kripa, D., \& Ajasllari, D. (2016). Factors Affecting the Profitability of Insurance Companies in Albania. European Journal of Multidisciplinary Studies, 1(1), 352-360.

Malik, H. (2011) Determinants of Insurance Companies' Profitability: An Analysis of Insurance Sector of Pakistan. Academy Reserve Journal, 2(1), 315-321.

Murphy, R. (2017). The Central Bank Thinks the Next Global Financial Crisis is Coming. Retrieved from: http://www.taxresearch.org.uk/Blog/2017/12/04/the-central-banks-bankthings-the-next-global-financial-crisis-is-coming/

Ngwili, K. P. (2013). The Relationship Between Liquidity and Profitability of Insurance Companies in Kenya. (Unpublished Thesis). Nairobi: University of Nairobi.

O'Grady, S. (2017). The Next Big Financial Crisis is on The Horizon - and This is Where it is Going to Come From. Retrieved from: http://www.independent. co.uk/voices/10-year-anniversary-banking-crash-recession-where-will-next-one-comefrom-a7886481.html

Ortyński, K. (2016). Determinants of Profitability of General Insurance Companies' Performance in Poland. Central European Review of Economics \& Finance, 12(2), 53-66.

Terrones, M. E., Scott, A., \& Kannan, P. (April). From Recession to Recovery: How Soon and How Strong? IMF: World Economic Outlook. Retrieved from https://www. $\mathrm{imf}$.org/external/pubs/ft/weo/2009/01/pdf/c3.pdf

Tomislava, P. K., Marko, M., Ivan, P. (2017). Profitability Determinants of Insurance Markets In Selected Central And Eastern European Countries. International Journal of Economic Sciences, 4(2), 313-322. 